\title{
ANTECEDENTS AND CONSEQUENCES OF MEANINGFUL WORK
}

\author{
SILVANIA S. ONÇA ${ }^{1}$ \\ (iD) https://orcid.org/0000-0002-1021-2168 \\ DIÓGENES S. BIDO \\ (iD) https://orcid.org/0000-0002-8525-5218
}

To cite this paper: Onça, S. S., \& Bido, D. S. (2019). Antecedents and consequences of meaningful work. Revista de Administração Mackenzie, 20(2). doi:10.1590/1678-6971/eRAMG190096

Submission: May 1, 2018. Acceptance: Aug. 22, 2018.

1 Universidade Federal do Sul e Sudeste do Pará (Unifesspa), Marabá, PA, Brazil.

2 Universidade Presbiteriana Mackenzie (UPM), São Paulo, SP, Brazil.

\section{(cc) BY




\section{ABSTRACT}

Purpose: This study assesses the influence of the importance of work and of creative self-concept on meaningful work and the influence of meaningful work on the employability of unemployed people living in the Southeast region of the State of Pará, in Brazil, aiming at a new job. Originality/value: This study also contributes to the literature, offering three new valid and reliable measuring instruments for the following constructs: Creative self-concept, Importance of work and Meaningful work.

Design/methodology/approach: The survey counts on the participation of 206 interviewees, and data were analyzed through confirmatory factorial analysis and structural equation modeling.

Findings: The ten constructs used in the model showed convergent validity, discriminant validity, and adequate reliability. In structural modeling, all three possibilities were confirmed, so the creative selfconcept and the importance of work explain $68 \%$ of the variance in meaningful work and, on its turn, meaningful work explains $67 \%$ of the variance in employability, in both cases, the explanatory power is great for the standards of behavioral sciences. This study makes a special contribution to address the importance of meaningful work in career counseling programs for unemployed people. It seems useful to point out a career orientation focused on meaningful work, aiming at increasing employability, as individuals with positive self-assessments are more likely to achieve a successful carrier based on personal effort. Nationally, such knowledge may foster public policy programs directed to unemployed people, focusing on their career.

\section{KEYWORDS}

Meaningful work. Creative self-concept. Importance of work. Employability. Structural equation modeling. 


\section{INTRODUCTION}

Considering that the organizations are seeking to improve their organizational performance, the meaningful work is being said, by scholars on the subject, as the concept that will overcome engagement and commitment at work (for example, Steger, 2016).

In its nature, the growth of meaningful work optimizes occupational opportunities in such a way that employee motivation, effort, and productivity are enhanced and that employees enthusiastically adopt attitudes of ownership, responsibility, and citizenship towards their organization, while simultaneously enjoying greater well-being, health, and belongingness.

In this perspective, we seek to identify which elements imply personal development and which variables have a positive impact on occupational health. Meaningful work, the importance of work, creative self-concept, and employability are concepts that involve strengthening people. Such constructs have been studied in the interdisciplinary field of Business Administration and Positive Psychology and are addressed as phenomena that may foster learning processes, improve performance and the interpersonal relationship in work environment, instead of focusing on treating weaknesses and diseases, which is consistent with the purpose of Positive Psychology (Seligman \& Csikszentmihalyi, 2000).

As individuals with positive self-assessments are more likely to attribute career success to personal capacity and effort, the knowledge of the relationships between the individual and contextual facilitators as the creative self-concept, importance of work, and employability is important for a better knowledge of the meaningful work of unemployed people. For organizations, the knowledge of these relationships may encourage the development of new people management policies. On the other hand, for the Brazilian states having high rates of unemployed people, such knowledge may foster public policy programs directed to empower this population. In the first quarter of 2018, the unemployment rate in Brazil reached 13.1\%, corresponding to 13.7 million unemployed people in the country, pursuant to IBGE (Instituto Brasileiro de Geografia e Estátistica [Brazilian Institute of Geography and Statistics]) data (2018).

Given the importance of the positive self-assessments for employability and successful career based on capacity development and personal effort, this study has the following as research question: "Does the creative selfefficacy and importance of work influence the meaningful work and the meaningful work influences employability of unemployed people living in 
the Southeast region of Pará?". And, as purpose, this study assesses the influence of the importance of work and of creative self-concept on meaningful work and the influence of meaningful work on the employability of unemployed persons living in the Southeast region of the State of Pará, aiming at a new job.

Additionally, this study adds, to the literature, adjustment and validation of three constructs measurement scales (meaningful work, importance at work, and creative self-concept) to the Brazilian culture, contributing to developing new surveys on the matter by applying reliable instruments from the methodological point of view.

Sections 2 to 5 present the theoretical definitions, antecedents, and consequence of the constructs studied, the possibilities of driving the study, and the structural model developing these aspects, which will be empirically tested. Section 6 describes the methodological procedures, section 7 presents and discusses the results, and section 8 the final considerations.

\section{MEANINGFUL WORK}

Meaningful work (MW), according to Steger, Dik, and Duffy (2012), is defined not as simply whatever work means to people (meaning), but as a work that is both significant and positive in valence (meaningfulness). For the authors, the positive valence of MW has a eudaimonic (growth and purpose-oriented) rather than hedonic (pleasure-oriented) focus.

Provided by Dik, Byrne, and Steger (2013) as the next variable responsible for reaching and improving organizational performance, MW is deemed, by all scholars on the subject, as a perception that a worker has on a personally significant contribution based on his/her effort (Steger, 2016) and what is or is not a work that has meaning is always based on subjectivity and interpretation (Rodrigues, Barrichello \& Morin, 2016).

Studies on the topic are, however, incipient. Bendassolli et al. (2015), by reviewing the Brazilian scientific literature on the senses and meaning of work, identified that the surveys on the topic were developed especially in the last decade and a half, predominantly in Psychology.

An important differentiation for the studies is between "meaningful work" and "meaning of work" (Steger, 2016). While "meaningful work" relates to the subjective experience that one's work or the carrier is significant, provides synergy with the meaning of life and benefits a greater good, the "meaning of work" regards the meaning, beliefs, definitions, and value that 
the individuals and groups assigned to the work as the main element of the human activity (Harpaz \& Flu, 2002, p. 641).

Steiger et al. (2012) identified three dimensions of MW that should be represented in surveys on the topic:

- Positive meaning of work: captures the feeling that people deem their work important and significant.

- Meaning making through work: captures people's broader context of the life of work.

- Greater good motivations: reflects common ideas that work is more significant if there is a broader impact on others.

Pursuant to Rosso, Deka, and WrzesniewskI (2010), at a personal level, the meaningful work is promoted by characteristics like an honest evaluation of the strengths and weaknesses, the desire to have a positive impact on others, and on the greater good. At the interpersonal level, the meaningful work is fostered by respectful relationships, a sufficient understanding of the social and political scenario of an organization, and opportunities to help and to be helped. As to organizational leadership, the meaningful work is fostered by clear communication of the values and mission of the organization together with an authentic adoption of these characteristics in the organization's operational culture and practice, authenticity, and ethical behavior of the leadership teams.

In the same direction, in the empirical study of Steiger, Dik, and Duffy (2012), MW was positively related to the variables of desirable work (organizational citizenship behaviors, career commitment, organizational commitment, job satisfaction, and intrinsic work motivations). Also, Kim and Beehr (2018) found negative correlations between meaningful work and emotional exhaustion.

MW was, still in the study of Steiger, Dik, and Duffy (2012), positively related to well-being (i.e., in life and life satisfaction) and negatively related to psychological suffering (hostility and depression). Accordingly, Allan et al (2016) found a negative correlation between meaningful work and depression, however, controlling job satisfaction, but the authors found no significant correlation between meaningful work, and stress and anxiety when moderated by job satisfaction.

Positive correlations were found between calling orientation, job design, relationship with colleagues, task significance, leadership strengthening, and perception of work in the sense of helping others, and meaningful work (Fouche, Rothmann, \& Van der Vyver, 2017; Tong, 2018; Allan, Duffy, \& Collisson, 2017; Kim, \& Beehr, 2018; Allan, Duffy, \& Collisson, 2018). 
As to consequences, the relationship between meaningful work and work environment, performance, contextual performance, self-reported performance, and life satisfaction were found (Fouche, Rothmann, \& Van der Vyver, 2017, Tong, 2018, Allan, Duffy, \& Collisson, 2017, Kim, \& Beehr, 2018).

If, on one side, there is progress in empirical researches involving meaningful work, on the other side, the distinction of the term with other constructs, like, for example, with the "importance at work", is still discussed in the literature. Its differentiation is discussed below.

\section{IMPORTANCE OF WORK}

Pursuant to Bustein (2011), work is responsible for a critical part of the identity of many people, as work often becomes a source of meaning, dignity, and importance, showing that there is a distinction between the constructs "meaning" and "importance" of work.

To care, pursuant to Rosenberg (1985, p. 215), refers to the "feeling that the individual makes a difference" and can be useful to understand the dynamic structure of the working experience of an individual in terms of social and interpersonal context. The interpersonal matter refers to the perception of a person that he/she is important to a specific group of persons (Rosenberg \& Mccullough, 1981), while the social matter is "the feeling of making a difference in a larger scheme of social and political events" (Rosenberg, 1985, p. 215).

Meaningful work is, however, the subjective experience of persons that their jobs, works, or carriers are significant, synergistic with the meaning and purpose of their lives and are capable of making a greater good and they are explained in three dimensions: positive meaning of work, meaning making through work, and greater good motivations, as already mentioned. Meaning and importance of work are both deemed relational results in the relational theory of working (Blustein, 2011).

Studies like the ones of Dixon and Kurpius (2008) and Tovar, Simon, and Lee (2009) found a positive influence of the interpersonal importance of work on mental health. Nevertheless, Amundson (1993) and Connolly and Myers found no support for the direct role of interpersonal matters to the well-being indices related to work, like job satisfaction. Therefore, Jung (2015) emphasized that interpersonal importance may not be sufficient to explain the influence of the importance of work on constructs related to well-being at work and resumed the social size of this importance proposed by Rosenberg (1985). 
Jung (2015) supported this hypothesis in studies on women's domestic work, such as, for example, the study of Schultheiss (2009). This is because care work in the domestic area is often not deemed as legitimate work, which is why it is frequently excluded from the theories and discussions of vocational psychology (Heppner, \& Jung, 2013). Schultheiss (2009) argued that economic structure rarely rewards care work. Additionally, Jung and Heppner (2015) found out that full-time mothers do not feel that their work is important nor are they satisfied with their work and life, mainly due to their perception of lack of recognition of the society for their work.

With that, Jung (2015) argued that the social matter of the importance of work can contribute to the psychological well-being of a person in the working context, as she may be interconnected to the society in general through the work together with the interpersonal aspect. The study of Jung (2015) pointed out moderate-to-strong associations of the social and interpersonal importance in work with meaningful work, job satisfaction, life satisfaction, organizational commitment, intentions of work leave, and positive affection. It also indicated a lack or weak associations with negative affection, age, and gender.

It seems, therefore, reasonable to assume that, both to employed and unemployed people, the social and interpersonal importance perceived can influence the perception of meaningful work and it is assumed that:

$\mathrm{H1}$ : the social and interpersonal importance of work influence the perception of meaningful work.

\section{CREATIVE SELF-CONCEPT}

Creative self-concept is a multifaceted construct, comprising characteristics like creative self-efficacy: the belief the person has in his own ability to produce creative outcome in a specific setting or in general (Beghetto, 2006, Tierney, \& Farmer, 2002) and creative personal identity: the role of creativity in identity and self-description (Tierney, \& Farmer, 2002, Karwowski et al., 2013).

Karwowski (2015) assessed the creative self-concept of 12,000 Polish people between 10 and 75 years old and identified that the creative selfefficacy is lower in adolescence, then increases in early adulthood, and decreases at the end of adulthood. In the case of creative personal identity, more visible changes were observed in adolescence, suggesting that school and development may have an important influence on this aspect of the creative self-concept. 
It was already found that creative self-efficacy is positively related to creative personality (Karwowski, 2012), innovative behavior (Hsu, Hou, \& Fan, 2011), and creative achievement (Batey, \& Furnham, 2008) and mediates the relationships between potential and creative achievement (Lim, \& Choi, 2009).

Also, creative self-efficacy was strongly related to the tendency to seek new experiences and acceptance of unpredictability and personal identity was related to the tendency to seek new experiences and involvement, in the study of Karwowski (2012). Previous studies showed that creative selfefficacy may be influenced by the transformational leadership of a teacher (Beghetto, 2006, Karwowski, 2011) or a manager (Tierney, \& Farmer, 2002) and that it is positively related to creative thought (Karwowski et al., 2013) and the five big personality traits: Openness to Experience, Extraversion, Conscientiousness, and Agreeableness, and Neuroticism (Karwowski et al., 2013). In the same study, creative self-efficacy and creative personal identity were positively correlated to emotional intelligence, intrinsic motivation, and self-esteem.

Jussim and Harber (2005) suggested that creative self-efficacy is developed under the influence of an individual's belief that creativity is an important element of the functioning itself and this belief - defined as a creative personal identity - can further increase the positive effects of creative self-efficacy in specific situations for carrying out a task. Therefore, one assumes that, if an individual perceives him/herself with creative selfefficacy and creative personal identity, it is possible that he/she also perceives a future work as significant, as he/she will be able to trust in the positive meaning of the work itself, in the meaning of carrying out the work in its context, and with a significant impact on others. Therefrom, the second hypothesis of this study:

H2: the creative self-concept positively influences the perception of meaningful work.

\section{EMPLOYABILITY OR SELF-EFFICACY IN TRANSITION TO WORK}

Focused on subjectivity, the employability, or self-efficacy in transition to work, may be defined as a belief in one's ability to organize and take actions like job search and adaptation to the world of work (Vieira, Maia, \& Coimbra, 2007). In this view, the concept is focused on the abilities and 
skills of the individual, and individual and contextual factors may influence the employability (Vieira \& Coimbra, 2006). The individual factors are, for example, interpersonal relationship, flexibility, autonomy, and ability to adapt to the environment. The contextual factors, however, are formed by relationships with family members, people from the academic and work settings.

Historically, the concept of employability was first used in order to identify persons qualified and skilled to enter the job market. Pursuant to Gazier (1999), employability was understood as the probability and time that a certain group used to take to find a job, so including the conditions of the job market.

Based on the Bandura's triadic relationship (1997), the concept of employability proposed by Vieira, Maia, and Coimbra (2007) and used in this study suggests that employability depends on self-efficacy beliefs. In the triadic model, the personal, biological, and cognitive factors, behavior, and environmental influences interrelate with each other (Bandura, 1997).

The construct of employability has three factors:

- Self-efficacy in adaptation to work: a trust perceived as an adaptation to work;

- Self-efficacy in emotional regulation: a trust perceived in emotional selfregulation in the process of finding a job;

- Self-efficacy in the job search: a trust perceived in behaviors of job search (Vieira et al. 2007).

Studies on employability background identified that self-esteem and selfefficacy, social support perceived, preparation for a career, and social integration predict employability (Gomes, 2014; Dias, 2015; and Fleming, 2015).

As consequences, Correia's study (2011) found negative and significant correlations between the self-efficacy beliefs in adaptation to work and perception of barriers like general discrimination, sexual discrimination, and lack of support. Couto's study (2012) found positive correlations with satisfaction with the relationships at work, satisfaction with the compensations at work, and satisfaction with the work content.

Gomes (2014) found that employed individuals had higher levels of self-esteem, self-efficacy, and employability compared to unemployed individuals. There was no gender differentiation and the qualification level had no influence on employability in Gomes' (2014) and Gouveia's (2011) researches. Dias' research (2015), however, gender was correlated with employability (higher scores for women). 
As Steiger, Dik, and Duffy (2012) found positive correlations between meaningful work and intrinsic work motivations and employability is understood, in this study, as an intrinsic motivation (a belief in one's ability to organize and take actions like job search and adaptation to the world of work, pursuant to Vieira, Maia, and Coimbra, 2007), we present the third hypothesis of the study:

H3: the perception of meaningful work positively influences employability.

Figure 5.1 illustrates the structural model that will be tested in this survey.

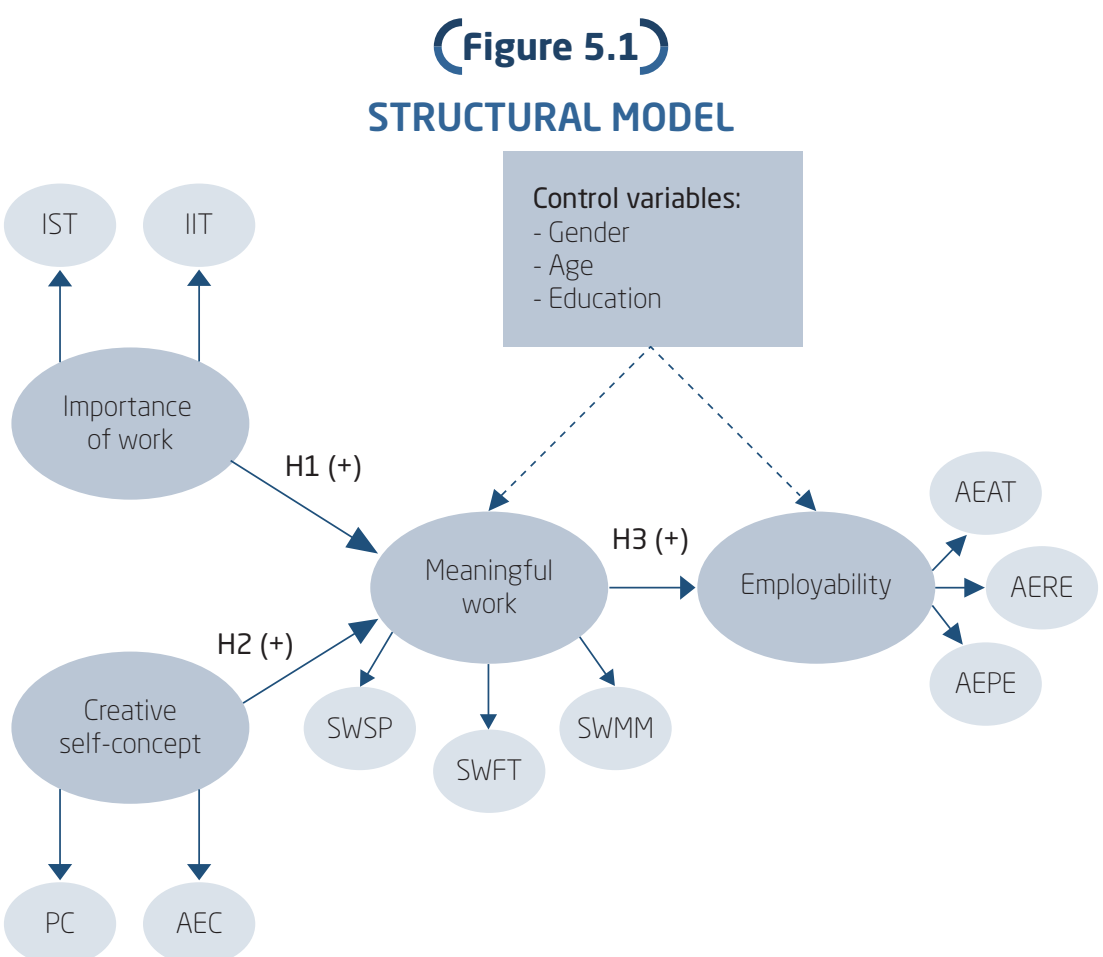

Legend: IST = Social Importance at Work; IIT = Interpersonal Importance at Work; CP = Creative Personality; AEC = Creative Self-efficacy; SWSP = Positive Meaning of Work; SWFT = Meaning Making through Work; SWMM = Greater Good Motivations; AEAT = Self-efficacy in Adaption to Work; AERE = Self-efficacy in Emotional Regulation; AEPE = Self-efficacy in Job Search.

Source: Adapted from Jung et al. (2017), Karwowski (2015), Steger, Dik, and Duffy (2012), Vieira and Coimbra (2006), and Vieira, Maia, and Coimbra (2007).

Dias (2015) found significant correlations between gender and employability, and age and education may correlate with meaningful work and employability (endogeneity), so we included these variables as controls in the model. 


\section{METHODOLOGICAL PROCEDURES}

\subsection{Instrument to collect data}

To measure the variables, we choose cross-cultural adaptation of three scales: Work Mattering Scale (WMS), Creative Self-Concept Scale (CSCS), The work as Meaning Inventory (WAMI).

The scale WMS, created and validated by Jung and Heppner (2017), assessed the importance of work. The scale has ten items related to the dimensions: 1. social (five items) and 2. interpersonal (five items). It was assessed with 7 points varying: from 1 = "strongly disagree" to 7 = "strongly agree".

The CSCS was created and validated by Karwowski (2015), assessed the creative self-concept, and has 11 items related to two dimensions: 1 . creative personality (five items) and 2. creative self-efficacy (six items), with 7 points: $1=$ "strongly disagree" and 7 = "strongly agree".

The scale WAMI was created and validated by Steger et al. (2012) and measured the meaningful work. The instrument originally had ten items distributed in three factors: 1 . positive meaning (four items), 2. meaning making through work (three items), and 3. greater good motivations (three items). The scale was assessed by using 7 points: from $1=$ "absolutely untrue" to 7 = "absolutely true".

Furthermore, the employability scale was used: Self-Efficacy in Transition to Work (AETT) was created and validated by Vieira and Coimbra (2006) and Vieira et al. (2007) already used in employed and unemployed people and college students by Gomes (2014) and adjusted to the Brazilian culture by the Onça (2017) in a sample of unemployed individuals. Originally, the scale has 28 items. In this study we used 15 items related to three dimensions: 1. self-efficacy in adaptation to work: (five items), 2. selfefficacy in emotional regulation (five items), and 3. self-efficacy in job search (five items). The scale uses 7 points varying: from 1 = "not confident at all" to $7=$ "very confident".

A sociodemographic questionnaire was used in order to describe participation in the study.

\subsection{Pre-test}

After translating the items of the scales adjusted to the Brazilian culture, we performed face validation and semantics of the items that compose the 
instruments, as recommended by Netemeyer, Bearden, and Sharma (2003). The items showing comprehension difficulties were adjusted to become understandable to the target audience.

The questionnaire was then submitted to a pre-test with 52 unemployed individuals. The confirmatory factorial analysis (CFA) was used to validate the measurement model as to the convergent validity, discriminant validity, and reliability and the software SmartPLS 3.2.6 (Ringle, Wende \& Becker, 2015) was used, which shows no estimation problems (non-convergence of the algorithm), like the most appropriate method (based on covariance), which was used subsequently, in the final analysis, but provides sufficient information to decide item fitness. While the values of the average variance extracted (AVE) and composite reliability (CR) are adequate (AVE really close to $50 \%$ and $C C \geq 0.7$ ), it was noted that the reverse item belonging to dimension "Greater Good Motivations" of the meaningful work scale (SWMM3) showed low factor loading and was reworked. Also, two items were added to this size (SWMM11 and SWMM12), inspired in the meaning of work scale of Fernandes, Gonçalves, and Oliveira (2012) in order to increase the reliability of the dimension. The items can be found in Appendix A.

\subsection{Data collection}

The questionnaire was provided in a form (paper) to the unemployed individuals of the employment agency SINE, located in Marabá, in the State of Pará. The unemployed individuals agreeing to participate in the study (convenience sample) received the instrument upon signature of the Free and Informed Consent (FIC). The formal consent of the person in charge of the agency was obtained for the survey. The objectives of the survey were explained and informed that the results would be analyzed collectively so the individual answers could not be identified. The questionnaires and the FICs should be returned in two separate containers to ensure secrecy of the interviewee's identity, thus avoiding identification of the interviewee.

The amount of 206 valid questionnaires was deemed adequate, as exceeded the number of the minimum sample required of 190 cases suggested by Soper (2018) to detect the size of the average effect $(r=0.3$ in Cohen classification, 1988) as significant to $5 \%$, with a statistical power of 0.8 .

\subsection{Data analysis}

The first stage of the analysis was "cleaning": of the 228 questionnaires received, 16 were excluded due to their atypical nature and also other six cases, due to lack of an answer for five or more items of the total 48, which resulted in a valid sample of 206 cases. 
The atypical cases were identified as follows:

- For each interviewee, the percentage of equal answers was assessed for the 48 items.

- When this percentage was equal to or greater than $90 \%$, the interviewee was identified as atypical (as he/she is not expected to give the same answer for different items, these cases were probably answered without properly paying attention to what was asked), therefore, 16 cases were excluded.

This criterion has been used in internal researches like ESS EduNet (2018), as the variables showed no normal distribution, to use the z-score criterion higher than 3.

Next, the measurement model was assessed in two stages:

- First, a confirmatory factorial analysis (CFA) with ten first-order latent variables (LV) through the lavaan package of software R (Rosseel, 2018) with estimation based on the polychoric correlation matrix and WLSMV method, which is recommended for ordinal data (Beaujean, 2014).

- Second, another CFA assessed the validity and reliability of secondorder LVs, which would be used in the structural model.

For the last stage, we performed structural equation modeling.

In both CFAs, the criteria recommended by Brown (2006), Fornell and Larcker (1981), and Hair Jr. et al. (2009) were used to assess fitness, i.e.:

- GoF - Goodness of Fit: chi-square/degrees of freedom $\leq$ 3; CNI, TLI, $\mathrm{RNI} \geq 0.92$; RMSEA $\leq 0.08$.

- The convergent validity was measured by the average variance extracted $($ AVE $\geq 0,5)$.

- Discriminant validity: 1. by using Fornell and Larcker criterion, the AVE square root should be higher than the correlations between the LVs; 2. by using the Brown and Hair Jr. et al. criterion, the correlation between both LVs should be tested to be equal to 1 .

- Reliability was measured by omega, which is a composite reliability measure and is available in the package semTools of software R.

\section{RESULTS}

In this section, we presented the results related to the definition of the sample, assessment of the measurement model (validity and reliability of the constructs) and the structural model. 


\subsection{Demographics}

Figure 7.1.1 presents the characteristics of participants in this survey, which are resumed as follows: 1. adults with an average age of 32.5 years, with the 1 st quartile equal to 25 years old and the 3rd quartile equal to 37 years old (50\% central); 2. majority male $(77 \%)$; 3 . high school $(53 \%)$; 4. married $(55 \%)$; 5 . have one or two children $(52 \%)$; 6 . half of them are solely responsible for household income.

(Figure 7.1.1)

DESCRIPTIVE STATISTICS OF THE DEMOGRAPHIC VARIABLES

\begin{tabular}{|c|c|c|}
\hline Age & (years) & \\
\hline Mean & 32.5 & \\
\hline Standard deviation & 9.3 & \\
\hline Minimum & 18 & \\
\hline $1^{\text {st }}$ quartile & 25 & \\
\hline Median & 32 & \\
\hline $3^{\text {rd }}$ quartile & 37 & \\
\hline Maximum & 64 & \\
\hline Gender & $\mathrm{n}$ & $\%$ \\
\hline Female & 46 & $22 \%$ \\
\hline Male & 158 & $77 \%$ \\
\hline Missing & 2 & $1 \%$ \\
\hline Education & $n$ & $\%$ \\
\hline $\begin{array}{l}\text { Elementary School } \\
\text { incomplete }\end{array}$ & 24 & $12 \%$ \\
\hline Middle Scholl incomplete & 16 & $8 \%$ \\
\hline High School incomplete & 38 & $18 \%$ \\
\hline High School & 109 & $53 \%$ \\
\hline $\begin{array}{l}\text { Higher Education } \\
\text { incomplete or complete }\end{array}$ & 19 & $9 \%$ \\
\hline
\end{tabular}

\begin{tabular}{lcc}
\hline Number of children & $\mathrm{n}$ & $\%$ \\
\hline 0 & 44 & $21 \%$ \\
\hline 1 & 52 & $25 \%$ \\
\hline 2 & 55 & $27 \%$ \\
\hline 3 & 15 & $7 \%$ \\
\hline 4 or more & 16 & $8 \%$ \\
\hline Missing & 24 & $12 \%$ \\
\hline
\end{tabular}

\begin{tabular}{lcc}
\hline $\begin{array}{l}\text { Only member responsible } \\
\text { for household income? }\end{array}$ & $\mathrm{n}$ & $\%$ \\
\hline Yes & 100 & $49 \%$ \\
\hline No & 88 & $43 \%$ \\
\hline Missing & 18 & $9 \%$ \\
\hline Marital status & $\mathrm{n}$ & $\%$ \\
\hline Single & 78 & $38 \%$ \\
\hline Married & 113 & $55 \%$ \\
\hline Others & 7 & $3 \%$ \\
\hline Missing & 8 & $4 \%$ \\
\hline Total & 206 & $100 \%$ \\
\hline
\end{tabular}

Note: For age, there were seven missing cases and we assigned the average rounded to the integer number. For gender, the adjustment to the model did not change by attributing masculine or feminine and the parameters of the model showed some difference of about thousandths (Figure 7.3.1). 


\subsection{Assessment of the measurement model}

Figure 7.2.1 presents the results of the CFA with ten first-order LVs. The model showed proper adjustment indices (GoF), as presented in the footnote of Figure 7.2.1. The convergence validity was deemed adequate, as the AVE values are higher than 0.5, except for LV ST_swsp (positive Meaning, the dimension of the meaningful work), which came to a close value (0.47).

As to the discriminant validity, the correlations in bold indicate a lack of discriminant validity pursuant to Fornell and Larcker's criterion (1981) and, for this reason, the discriminant validity was reassessed compared to the free model with a restricted model where this correlation was established in value 1 (Brown, 2006, Hair Jr. et al., 2009), showing a significant difference $(\mathrm{p}<0.001)$ in all cases, which is favorable to the maintenance of the LVs, how they were modeled, i.e., they are highly correlated with each other, but are different constructs (the correlation of 0.95 was also tested, which also showed $\mathrm{p}<0.001)$. Additionally, the fact that they have second-order LVs dimensions, these high correlations are favorable to the results for convergent validity and reliability of second-order LVs.

Finally, the reliability is suitable for all LVs, with omega equal to or greater than 0.7. It is important to note that the AVE and the omega results could be improved by eliminating items with lower factor loadings, but this would hinder the content validity and comparability of the current results with a previous survey (DeVellis, 2016), so all 48 initial items were kept in all models tested. 


\section{(Figure 7.2.1)}

\section{CORRELATION MATRIX BETWEEN THE FIRST-ORDER LATENT VARIABLES $(\mathrm{N}=206)$}

\begin{tabular}{|c|c|c|c|c|c|c|c|c|c|c|}
\hline $1^{\text {st }}$ order LV & 1 & 2 & 3 & 4 & 5 & 6 & 7 & 8 & 9 & 10 \\
\hline I-WM_societal & 0.770 & & & & & & & & & \\
\hline 2-WM_interpes & 0.701 & 0.763 & & & & & & & & \\
\hline 3-PC_pci & 0.347 & 0.426 & 0.772 & & & & & & & \\
\hline 4-PC_aec & 0.406 & 0.545 & 0.857 & 0.717 & & & & & & \\
\hline 5-ST_swsp & 0.529 & 0.329 & 0.343 & 0.374 & 0.685 & & & & & \\
\hline 6-ST_swft & 0.426 & 0.236 & 0.286 & 0.206 & 0.691 & 0.782 & & & & \\
\hline 7 -ST_swmm & 0.587 & 0.406 & 0.241 & 0.207 & 0.737 & 0.838 & 0.758 & & & \\
\hline 8 -EMP_aeat & 0.520 & 0.590 & 0.407 & 0.583 & 0.496 & 0.351 & 0.538 & 0.763 & & \\
\hline 9 -EMP_aere & 0.458 & 0.429 & 0.339 & 0.532 & 0.462 & 0.207 & 0.356 & 0.835 & 0.829 & \\
\hline 10-EMP_aepe & 0.459 & 0.415 & 0.456 & 0.564 & 0.443 & 0.212 & 0.266 & 0.511 & 0.640 & 0.738 \\
\hline omega & 0.802 & 0.847 & 0.858 & 0.798 & 0.696 & 0.777 & 0.842 & 0.839 & 0.885 & 0.786 \\
\hline avevar & 0.593 & 0.583 & 0.596 & 0.514 & 0.470 & 0.611 & 0.575 & 0.583 & 0.687 & 0.545 \\
\hline Minimum & 1.2 & 1.0 & 1.8 & 2.2 & 2.0 & 1.0 & 1.2 & 2.6 & 2.2 & 1.4 \\
\hline $1^{\text {st }}$ quartile & 4.6 & 4.6 & 4.8 & 4.8 & 5.5 & 5.3 & 5.7 & 6.0 & 5.2 & 4.0 \\
\hline Median & 5.8 & 5.6 & 5.8 & 5.7 & 6.3 & 6.7 & 6.4 & 6.6 & 6.4 & 5.2 \\
\hline $3^{\text {rd }}$ Quartile & 6.6 & 6.4 & 6.6 & 6.3 & 6.8 & 7.0 & 7.0 & 7.0 & 7.0 & 6.2 \\
\hline Maximum & 7.0 & 7.0 & 7.0 & 7.0 & 7.0 & 7.0 & 7.0 & 7.0 & 7.0 & 7.0 \\
\hline
\end{tabular}

Note 1: The CFA was estimated in lavaan based on polychoric correlations and WLSMV method. Omega is a composite reliability measure available in package semTools of software $R$.

Fit index of the CFA model with first-order LV: chi-square $=1424.867$; degrees of freedom $=1035$; chi-square/ degrees of freedom $=1.38 ; \mathrm{CFI}=0.95 ; \mathrm{TLI}=0.95 ;$ RNI.SCALED $=0.989 ;$ RMSEA $=0.043 ;$ RMSEA (I.C. to 90\%) $=$ 0.037 to 0.048

Note 2: The factor scores were calculated as simple arithmetic means of their items and the distribution was asymmetric (more enlonged tail to the left); it was decided to use the median and quartiles to discuss the distribution of the scores instead of using average values.

Legend: WM_societal = Social Importance at Work; WM_interpes = Interpersonal Importance at Work; PC_Pci = Creative personality; PC_aec = Creative self-concept; ST_swsp = Positive meaning; ST_swft = Meaning Making through Work; ST_swmm = Greater Good Motivations; EMP_aeat = Self-efficacy in Adaptation to Work; EMP_aere = Self-Efficacy in Emotional Regulation; EMP_aepe = Self-efficacy in Job Search.

The diagonal values are the square root of the mean-variance extracted (AVE).

The grey cells are correlations between first-order LV, measuring the same construct (second-order LV). 
The second CFA included the four second-order LV, composing the structural model, namely: Importance of Work, Creative self-concept, Meaningful work, and Employability. The results presented in Figure 7.2.2 are adequate in all criteria: GoF, convergence validity (AVE > 0.5), discriminant validity (values outside the diagonal are smaller than the diagonal values), and reliability (omega $>0.7$ ).

\section{(Figure 7.2.2)}

CORRELATION MATRIX BETWEEN THE LATENT VARIABLES OF THE STRUCTURAL MODEL ( $=206)$

\begin{tabular}{l|c|ccc}
\hline \multicolumn{1}{c}{ LV of the structural model } & 1 & 2 & 3 & 4 \\
\cline { 1 - 2 } 1- Importance of work & 0.838 & \multicolumn{2}{c}{} & \\
\cline { 1 - 2 } 2-Creative self-concept & 0.561 & 0.927 & \multicolumn{2}{c}{} \\
\cline { 1 - 2 } 3-Meaningful work & 0.595 & 0.330 & 0.875 & \\
\hline 4-Employability & 0.684 & 0.625 & 0.518 & 0.838 \\
\hline omega & 0.825 & 0.925 & 0.922 & 0.900 \\
\hline avevar & 0.702 & 0.859 & 0.766 & 0.702 \\
\hline
\end{tabular}

Note 1: The CFA was estimated in lavaan based on polychoric correlations and WLSMV method. Omega is a composite reliability measure available in package semTools of software $R$.

Fit index of the CFA model with second-order LV: chi-square = 1562.571; degrees of freedom = 1066; chi-square/ degrees of freedom $=1.47 ; \mathrm{CFI}=0.94 ; \mathrm{TLI}=0.94 ;$ RNI.SCALED $=0.986 ;$ RMSEA = 0.048; RMSEA (I.C. to 90\%) $=$ 0.043 to 0.053 .

Source: Elaborated by the authors.

Upon conclusion of the assessment of the measurement model, the results for the structural equation modeling will test the hypotheses in the next section.

\subsection{Assessment of the structural model}

Figure 7.3.1 presents the results of two structural models, the first includes the control variables, which showed no significant relation with any LV of the structural model, for this reason, they were excluded from the model, which generated the results of model 2 . Both models showed adequate GoF (footnote of Figure 7.3.1).

Both model 1 and model 2 confirmed the three hypotheses, so creative self-concept and importance of work explain $68 \%$ of the variance in meaningful work and, on its turn, meaningful work explain $67 \%$ of the 
variance in employability, in both cases the explanatory power is great for behavioral science standards (Cohen, 1988).

\section{(Figure 7.3.1)}

STRUCTURAL COEFFICIENTS ( $\mathrm{N}=206$ )

\begin{tabular}{|c|c|c|c|c|c|c|c|}
\hline Model 1 & Hypothesis & $\begin{array}{c}\text { Non- } \\
\text { standardized } \\
\text { coefficient }\end{array}$ & $\begin{array}{l}\text { Standard } \\
\text { error }\end{array}$ & $P$ value & $\begin{array}{l}\text { Standardized } \\
\text { coefficient }\end{array}$ & $\mathrm{R}^{2}$ & $R^{2}$ ajust. \\
\hline \multicolumn{8}{|l|}{ Meaningful work } \\
\hline Importance of Work & $\mathrm{HI}(+)$ & 1.347 & 0.280 & 0.000 & 0.698 & \multirow{5}{*}{0.731} & \multirow{5}{*}{0.724} \\
\hline Creative self-concept & $\mathrm{H} 2(+)$ & 0.444 & 0.153 & 0.004 & 0.230 & & \\
\hline Age & control & 0.019 & 0.025 & 0.444 & 0.093 & & \\
\hline Education & control & 0.125 & 0.176 & 0.479 & 0.073 & & \\
\hline Gender_male & control & -0.382 & 0.465 & 0.411 & -0.083 & & \\
\hline \multicolumn{8}{|l|}{ Employability } \\
\hline Meaningful work & $\mathrm{H} 3(+)$ & 0.761 & 0.155 & 0.000 & 0.809 & \multirow{4}{*}{0.696} & \multirow{4}{*}{0.690} \\
\hline Age & control & 0.008 & 0.018 & 0.668 & 0.040 & & \\
\hline Education & control & 0.276 & 0.154 & 0.073 & 0.173 & & \\
\hline Gender_male & control & 0.214 & 0.420 & 0.611 & 0.049 & & \\
\hline Model 2 & Hypothesis & $\begin{array}{c}\text { Non- } \\
\text { standardized } \\
\text { coefficient }\end{array}$ & $\begin{array}{l}\text { Standard } \\
\text { error }\end{array}$ & $P$ value & $\begin{array}{l}\text { Standardized } \\
\text { coefficient }\end{array}$ & $\mathrm{R}^{2}$ & $R^{2}$ ajust. \\
\hline \multicolumn{8}{|l|}{ Meaningful work } \\
\hline Importance of Work & $\mathrm{HI}(+)$ & 1.157 & 0.243 & 0.000 & 0.651 & \multirow{2}{*}{0.683} & \multirow{2}{*}{0.680} \\
\hline Creative self-concept & $\mathrm{HZ}\left({ }^{+}\right)$ & 0.465 & 0.150 & 0.002 & 0.262 & & \\
\hline \multicolumn{8}{|l|}{ Employability } \\
\hline Meaningful work & $\mathrm{H} 3(+)$ & 0.807 & 0.163 & 0.000 & 0.820 & 0.673 & 0.673 \\
\hline
\end{tabular}

Note 1: The CFA was estimated in lavaan based on polychoric correlations and WLSMV method. The item age was included in the model as a scalar variable and education as ordinal.

Fit index of model 1 ; chi-square $=1960.662$; degrees of freedom $=1206$; chi-square/degrees of freedom $=1.63$; CFI = 0.91; TLI = 0.90; RNI.SCALED = 0.978; RMSEA = 0.055; RMSEA (I.C. to 90\%) 0.051 to 0.060 .

Fit index of model 2: chi-square $=1799.551$; degrees of freedom $=1068$; chi-square/degrees of freedom $=1.68$; CFI = 0.91; TLI = 0.91; RNI.SCALED = 0.979; RMSEA = 0.058; RMSEA (I.C. to 90\%) 0.053 to 0.062 .

Source: Elaborated by the authors. 
Figure 7.3.1 shows that the meaningful work is a strong predictor $(\beta=$ 0.809, $\mathrm{p}<0.01$ ) of employability and Figure 7.2.1 shows that the medians for their three dimensions are between 6.3 and 6.7 (in a scale from 1 to 7 ) and the 1st quartile between 5.3 and 5.7 (or $75 \%$ of the interviewees above 5.3); therefore, they are pretty high values.

A possible explanation for such high values in meaningful work may be in the importance of work, which showed a high coefficient $(\beta=0.698$, $\mathrm{p}<0.01)$.

Roughly speaking, the education level is homogeneous and is not high (only $9 \%$ had higher education incomplete or complete), and maybe this is the reason why the education level failed to show significant relations with the other variables of the model, and if there was a larger number of individuals with higher education level, they might give up their careers or have to obtain more qualification to remain in the position, resulting in lower values for the meaningful work variable.

\section{FINAL CONSIDERATIONS}

This study assesses the influence of the importance of work and of creative self-concept on meaningful work and the influence of meaningful work on employability of unemployed persons living in the Southeast region of the State of Pará, aiming at a new job, which topic should be studied, as recommended by the authors of the WMS scale, Steger, Dik, and Duffy (2012).

Pursuant to the results presented, the unemployed individual showed high levels of meaningful work and may pose a lower risk of turnover, greater commitment to the organization, and higher involvement in organizational citizenship behaviors (Steger et al. 2012), desirable features within organizations.

All hypotheses in the study were confirmed. Thus, we note that the importance of work and creative self-concept had an influence on meaningful work and, on its turn, meaningful work had an influence on the employability of the participants. This means that the more unemployed people perceive that work is important to the interpersonal relationships and the society and the higher the levels of creative self-efficacy and creative personality of these people, the more the work will be perceived as meaningful for them. Additionally, the more participants perceive the work as meaningful, the more they will have the confidence to organize and act as to search for jobs and adaptation to the world of work. 
This study makes a special contribution to address the importance of meaningful work in career counseling programs for unemployed people. It seems useful to point out a career orientation focused on meaningful work, aiming at increasing employability, as individuals with positive self-assessments are more likely to achieve a successful carrier based on personal effort.

It is worth mentioning, however, that the creative self-concept may further increase the positive effects in specific situations when performing a task. Thus, for organizations, the knowledge of the results of this study may encourage the development of new people management policies, both in engagement and retention of workers, aiming at developing the creative self-concept, importance, and meaningful work.

Nationally, such knowledge may foster public policy programs directed to unemployment people, focusing on their career.

This study also contributes to the literature, offering three new valid and reliable measuring instruments for the following constructs: creative self-concept, importance of work and meaningful work.

\subsection{Limitations}

The main limitations of this study are: 1. the sample was obtained by convenience, that is the reason why the results are not generalizable for a specific population, even if the authors seek to collect data from a homogeneous sample (unemployed individuals and job seekers); and 2. the cross-sectional analysis is limited in terms of causal inferences, so even if the construction of the hypothesis has this nature and the hypotheses are confirmed, it is not possible to be conclusive in causal terms.

Considering the results obtained and the limitations mentioned, the following is suggested for future surveys: qualitative research (interviews) with people who had extreme scores (high and lows) in the constructs studied, as to enrich the understanding of the phenomenon and the relations between the constructs. It makes no sense to think of a longitudinal survey with the type of sample used in this survey, because people are expected to re-enter the labor market over time; however, it would be interesting to monitor a group of people for a few years to understand how contextual changes influence on how they evaluate the constructs treated in this survey. 


\section{ANTECEDENTES E CONSEQUÊNCIAS DO TRABALHO SIGNIFICATIVO}

\section{RESUMO}

Objetivo: Neste estudo analisa-se a influência da importância do trabalho e do autoconceito criativo no trabalho significativo e deste na empregabilidade de pessoas em situação desemprego no sudeste do estado do Pará, com vistas a um novo posto de trabalho.

Originalidade/valor: Este estudo contribui ainda para a literatura oferecendo três novos instrumentos de medida válidos e fidedignos para os construtos: autoconceito criativo, importância do trabalho e trabalho significativo.

Design/metodologia/abordagem: A pesquisa é do tipo levantamento (survey) com a participação de 206 respondentes, com os dados analisados por meio da análise fatorial confirmatória e modelagem de equações estruturais.

Resultados: Os dez construtos usados no modelo apresentaram validade convergente, validade discriminante e confiabilidade adequadas. No modelo estrutural, as três hipóteses foram confirmadas, de modo que o autoconceito criativo e a importância do trabalho explicam $68 \%$ da variância do trabalho significativo, e, por sua vez, o trabalho significativo explica $67 \%$ da variância da empregabilidade; em ambos os casos, o poder explicativo é grande para os padrões da área de ciências do comportamento. Este estudo contribui, sobretudo, para elucidar a importância do trabalho significativo em programas de orientação da carreira para pessoas em situação de desemprego. Parece útil indicar orientação de carreira centrada no trabalho significativo com vistas a aumentar a empregabilidade, já que indivíduos com autoavaliações positivas são mais prováveis de obter sucessos de carreira a partir do esforço pessoal. Nacionalmente, tais conhecimentos poderão fomentar programas de políticas públicas voltadas para o desenvolvimento de pessoas em situação de desemprego centradas na orientação de carreira.

\section{PALAVRAS-CHAVE}

Trabalho significativo. Autoconceito criativo. Importância do trabalho. Empregabilidade. Modelagem de equações estruturais. 


\section{REFERENCES}

Allan, B. A., Dexter, C., Kinsey, R., \& Parker, S. (2016). Meaningful work and mental health: Job satisfaction as a moderator. Journal of Mental Health, 27(1), 1-7. doi:10.1080/09638237.2016.1244718

Allan, B. A., Duffy, R. D., \& Collisson, B. (2017). Helping others increases meaningful work: Evidence from three experiments. Journal of Counseling Psychology, 65 (2), 155-165. doi:10.1037/cou0000228

Allan, B. A., Duffy, R. D., \& Collisson, B. (2018). Task significance and performance: Meaningfulness as a mediator. Journal of Career Assessment, 26(1), 172-182. doi:10.1177/1069072716680047

Amundson, N. E. (1993). Mattering: A foundation for employment counseling and training. Journal of Employment Counseling, 30(1), 146-152. doi:10.1002/j.2161-1920.1993.tb00173.x

Bandura, A. (1977). Self-efficacy: Toward a unifying theory of behavior change. Psychological Review, 84(2), 191-215. doi:10.1037/0033-295X. 84.2.191

Batey, M., \& Furnham, A. (2008). The relationship between measures of creativity and schizotypy. Personality and Individual Differences, 8(1), 816-821. doi:10.1016/j.paid.2008.08.014

Beaujean, A. A. (2014). Latent Variable Modeling Using R: A step-by-step guide. New York, NY: Routledge. doi:10.4324/9781315869780

Beghetto, R. A. (2006). Creative self-efficacy: Correlates in middle and secondary students. Creativity Research Journal, 18(1), 447-457. doi:10.12 07/s15326934crj1804_4

Bendassolli, P. F., Coelho-Lima, F., Pinheiro, R. A., \& GÊ, P. C. S. (2015). The Brazilian scientific production on sense and meaning of work: Reviewing terminological use and current thematic classifications. Avances en Psicología Latinoamericana, 33(2), 203-221. doi:10.12804/ap133.02.2015.03

Blustein, D. L. (2011). A relation theory of working. Journal of Vocational Behavior, 79(1), 1-7. doi:10.1016/j.jvb.2010.10.004

Brown, T. A. (2006). Confirmatory factor analysis for applied research. New York, NY: The Guilford Press.

Cha, E., Kim, K. H., \& Erlen, J. A. (2007). Translation of scales in crosscultural research: Issues and techniques. Journal of Advanced Nursing, 58(4), 386-395. doi:10.1111/j.1365-2648.2007.04242.x 
Cohen, J. (1988). Statistical power analysis for the behavioral sciences (2nd ed.). New York, NY: Academic Press. doi:10.1016/B978-0-12-179060-8.50012-8

Connolly, K. M., \& Myers, J. E. (2003). Wellness and mattering: The role of holistic factors in job satisfaction. Journal of Employment Counseling, 40(1), 152-160. doi:10.1002/j.2161-1920.2003.tb00866.x

Correia, F. F. (2011). Autoeficácia na transição para o trabalho e percepção de barreiras em alunos do $12^{\circ}$ ano de cursos profissionais (Master's thesis). Universidade de Lisboa, Lisbon, Portugal.

Couto, M. J. B. L. F. (2012). Autoeficácia e satisfação no trabalho em técnicos de diagnóstico e terapêutica (Master's thesis). Retrieved from http://repositorio. ul.pt/bitstream/10451/5076/1/ulfpie039696_tm.pdf

DeVellis, R. F. (2016). Scale development: Theory and applications (4th ed.) Thousand Oaks, CA: Sage.

Dias, M. A. F. (2015). Estudantes do ensino superior e transição para o mercado de trabalho (Master's thesis). Retrieved from https://repositorio.uac.pt/ bitstream/10400.3/3767/1/DissertMestradoMarinaAlexandraFerreira Dias2016.pdf

Dik, B. J., Byrne, Z. S., \& Steger, M. F. (2013). Purpose and meaning in the workplace. Washington, DC: APA Books. doi:10.1037/14183-000

Dixon, S. K., \& Kurpius, S. E. R. (2008). Depression and college stress among university undergraduates: Do mattering and self-esteem make a difference? Journal of College Student Development, 49(5), 412-424. doi:10.1353/csd.0.0024

ESS EduNet - The European Social Survey Education Net. First round of preparation, cleaning and recoding. Retrieved from http://essedunet.nsd.uib. no/cms/topics/1/4/2.html

Fleming, S. C. R. (2015). Envolvimento acadêmico e autoeficácia na transição para o trabalho: Um estudo com universitários concluintes (Master's thesis). Retrieved from https://repositorio.ufba.br/ri/handle/ri/21266

Fernandes, F. S., Gonçalves, C. M., \& Oliveira, P. J. (2012). Adaptação e validação da escala de significados atribuídos ao trabalho: ESAT. Revista Brasileira de Orientação Profissional, 13(2), 183-195.

Fornell, C., \& Larcker, D. F. (1981). Evaluating structural equation models with unobservable variables and measurement error. Journal of Marketing Research, 18(1), 39-50. doi:10.2307/3151312

Fouche, E., Rothmann, S., \& Van der Vtver, C. (2017). Antecedents and outcomes of meaningful work among schoolteachers. Journal of Industrial Psychology, 43(0), 1-10. doi:10.4102/sajip.v43i0.1398 
Gazier, B. (1999). Employability: Concepts and policies. Berlin, DE: European Commission; Employment and Social Affairs.

Gomes, N. A. S. (2014). Autoestima, autoeficácia, e empregabilidade subjectiva em empregados, desempregados, e estudantes do ensino superior (Master's thesis). Retrieved from http://recil.grupolusofona.pt/handle/10437/5745

Hair Jr., J. F., Black, W. C, Babin, B., Anderson, R. E., \& Tatham, R. L. (2009). Análise multivariada de dados (6th ed.). Porto Alegre, RS: Bookman.

Harpaz, I., \& Fu., X. (2002). The structure of the meaning of work: A relative stability amidst change. Human Relations, 55(1), 639-667. doi:10.1177/00 18726702556002

Heppner, M., \& Jung, A. (2013). Gender and social class: Powerful predictors of a life journey. In W. B. Walsh, M. Savickas, P. J. Hartung (Eds.). Handbook of Vocational Psychology: Theory, Research, and Practice. 4th ed. (pp. 81-102). New York, NY: Routledge.

Hsu, L. A., Hou, S. T., \& Fan, H. L. (2011). Creative self-efficacy and innovative behavior in a service setting: Optimism as a moderator. Journal of Creative Behavior, 4(1), 258-272. doi:10.1002/j.2162-6057.2011.tb 01430.x

IBGE (2018, March). Pesquisa Nacional por Amostra de Domicílios (PNAD). Retrieved from http://ibge.gov.br

Jung, A. (2015). Interpersonal and societal mattering in work: A review and critique. Career Development Quarterly, 63(1), 253-267. doi:10.1002/cdq. 12013

Jung, A., \& Heppner, M. J. (2015). Work of fulltime mothers: Putting voice to a relational theory of work. Career Development Quarterly, 63(1), 253-267. doi:10.1002/cdq. 12017

Jussim, L., \& Harber, K. D. (2005). Teacher expectations and self-fulfilling prophecies: Knowns and unknowns, resolved and unresolved controversies. Personality and Social Psychology Review, 9(1), 131-155. doi:10.1207/s1532 7957pspr0902_3

Karwowski, M. (2011). It doesn't hurt to ask... But sometimes it hurts to believe: Polish students' creative self-efficacy and its predictors. Psychology of Aesthetics, Creativity, and the Arts, 5(1), 154-164. doi:10.1037/a0021427

Karwowski, M. (2012). Did curiosity kill the cat? Relationship between trait curiosity, creative self-efficacy and creative personal identity. Europe's Journal of Psychology, 8(1), 547-558. doi:10.5964/ejop.v8i4.513 
Karwowski, M., Lebuda, I., Wisniewska, E., \& Gralewski, J. (2013). Big five personality factors as the predictors of creative self-efficacy and creative personal identity: Does gender matter? Journal of Creative Behavior, 47(1), 215-232. doi:10.1002/jocb.32

Karwowski, M. (2015). Development of the creative self-concept. Creativity: Theories Research-Applications, 2(1), 125-140. doi:10.1515/ctra-2015-0019

Kim, M., \& Beehr, T. A. (2018). Organization-based self-esteem and meaningful work mediate effects of empowering leadership on employee behaviors and well-being. Journal of Leadership and Organizational Studies, 25(4), 1-14. doi:10.1177/1548051818762337

Lim, H. S., \& Choi, J. N. (2009). Testing an alternative relationship between individual and contextual predictors of creative performance. Social Behavior and Personality, 37(1), 117-136. doi:10.2224/sbp.2009.37.1.117

Netemeyer, R. G., Bearden, W. O., \& Sharma, S. (2003). Scaling Procedures: Issues and applications. Thousand Oaks, CA: Sage. doi:10.4135/97814129 85772

Onça, S. S. (2017, November). Estudo da influência da percepção de suporte social na empregabilidade de pessoas em situação de desemprego do Sul e Sudeste do Pará. Anais do XX SEMEAD. São Paulo, SP, Brazil.

Ringle, C. M., Wende, S., \& Becker, J.-M. (2015). "SmartPLS 3.” [Software]. Boenningstedt: SmartPLS GmbH. Retrieved from http://www.smartpls.com

Rodrigues, A. L., Barrichello, A., \& Morin, E. M. (2016). Os sentidos do trabalho para profissionais de enfermagem: Um estudo multimétodos. Revista de Administração de Empresas, 56(2), 192-208. doi:10.1590/S0034759020160206

Rosenberg, M. (1985). Self-concept and psychological well-being in adolescence. In R. Leahy (Ed.). The development of the self (pp. 205-246). New York, NY: Academic Press.

Rosenberg, M., \& McCullough, B. C. (1981). Mattering: Inferred significance and mental health among adolescents. Research in Community and Mental Health, 2(1), 163-182.

Rosseel, Y. (2018). The lavaan tutorial. Retrieved from http://lavaan.ugent. be/tutorial/tutorial.pdf

Rosso, B. D., Dekas, K. H., \& Wrzesniewski, A. (2010). On the meaning of work: A theoretical integration and review. Research in Organizational Behavior, 30(1), 91-127. doi:10.1016/j.riob.2010.09.001

Schultheiss, D. E. P. (2009). To mother or matter can women so both? Journal of Career Development, 36(1), 25-48. doi:10.1177/0894845309340795 
Seligman, M. E. P., \& Csikszentmihalyie, M. (2000). Positive psychology: An introduction. American Psychologist, 55(1), 5-14. doi:10.1037/0003066X.55.1.5

Sharifirad, M. S. (2013). Transformational leadership, innovative work behavior, and employee well-being. Global Business Perspectives, 1(3), 198-225. doi:10.1007/s40196-013-0019-2

Soper, D. S. (2018). A-priori sample size calculator for structural equation models [Software]. Retrieved from http://www.danielsoper.com/statcalc

Steger, M., Dik, B. J., \& Duffy (2012). Measuring meaningful work: The work and meaning inventory (WAMI). Journal of Career Assessment, 20(3), 322-337. doi:10.1177/1069072711436160

Steger, M. (2016). Creating meaning and purpose at work. In L. G. Oades, M. Steger, \& A. D. Fave (Eds.). The Wiley Blackwell Handbook of the Psychology of Positivity and Strengths-Based Approaches at Work (pp. 60-81). West Sussex, UK: John Wiley \& Sons.

Tierney, P., \& Farmer, S. M. (2002). Creative self-efficacy: Its potential antecedents and relationship to creative performance. Academy of Management Journal, 45(1), 1137-1148. doi:10.5465/3069429

Vieira, D., \& Coimbra, J. (2006). Sucesso na transição escola-trabalho: A percepção de finalistas do ensino superior português. Revista Brasileira Orientação Profissional, 7, 1-10.

Vieira, D., Maia, J., \& Coimbra, J. (2007). Do ensino superior para o trabalho: Análise factorial confirmatória da escala de auto-eficácia na transição para o trabalho (AETT). Avaliação Psicológica, 6, 3-12.

Tong, L. (2018). Relationship between meaningful work and job performance in nurses. International Journal of Nursing Practice, 24(2), e12620. doi:10.11 11/ijn. 12620

Tovar, E., Simon, M. A., \& Lee, H. B. (2009). Development and validation of the college mattering inventory with diverse urban college students. Measurement and Evaluation in Conseling and Development, 42(1), 154-178. doi:10.1177/0748175609344091

\section{AUTHOR NOTES}

Silvania S. Onça, Centro de Ciências Sociais e Aplicadas (CCSA), Universidade Presbiteriana Mackenzie (UPM); \& Diógenes S. Bido, Faculdade de Economia, Administração e Contabilidade da Universidade de São Paulo (FEA), Universidade de São Paulo (USP). 
Silvania S. Onça is now Professor at Faculdade de Psicologia (Fapsi) at Universidade Federal do Sul e Sudeste do Pará (Unifesspa); \& Diógenes S. Bido is now Adjunct Professor at Centro de Ciências Sociais e Aplicadas (CCSA) at Universidade Presbiteriana Mackenzie (UPM) and research productivity schorlar (PQ) of Conselho Nacional de Desenvolvimento Científico e Tecnológico (CNPq), process number 314242/2018-0.

Correspondence concerning this article should be addressed to Diógenes S. Bido, Rua da Consolação, 930, Consolação, São Paulo, São Paulo, Brazil, CEP: 01302-907.

E-mail: diogenesbido@yahoo.com.br

\section{ACKNOWLEDGMENT}

To CNPq (Conselho Nacional de Desenvolvimento Científico e Tecnológico) for the productivity scholarship to the second author of this paper.

\section{(Appendix A) \\ SCALE ITEMS}

\begin{tabular}{|c|c|c|c|}
\hline LV | Item & Item & $\begin{array}{l}\text { Standardized } \\
\text { factor loading }\end{array}$ & $\begin{array}{c}\text { Mean } \\
\text { (scale from } \\
1 \text { to } 7 \text { ) }\end{array}$ \\
\hline \multicolumn{4}{|c|}{ WM_societal } \\
\hline ISTI & I think society will value the work I will do. & 0.602 & 5.4 \\
\hline IST2 & I feel that a future job meets a social need. & 0.739 & 5.5 \\
\hline IST3 & $\begin{array}{l}\text { I am connected to society through a future } \\
\text { work. }\end{array}$ & 0.788 & 5.3 \\
\hline IST4 & $\begin{array}{l}\text { People say that a future work will influence } \\
\text { your life. }\end{array}$ & 0.839 & 5.8 \\
\hline IST5 & A future work influences peoples' life. & 0.856 & 5.7 \\
\hline \multicolumn{4}{|c|}{ WM_interpes } \\
\hline IIT6 & $\begin{array}{l}\text { My future co-workers would be disappointed if } \\
\text { they knew I could leave my job. }\end{array}$ & 0.694 & 5.0 \\
\hline$\| T 7$ & I feel I will like my co-workers. & 0.728 & 5.7 \\
\hline ॥T8 & $\begin{array}{l}\text { My co-workers will value my ideas and } \\
\text { suggestions. }\end{array}$ & 0.795 & 5.3 \\
\hline IIT9 & $\begin{array}{l}\text { My boss/supervisor will be disappointed if they } \\
\text { knew i could leave my job. }\end{array}$ & 0.719 & 5.2 \\
\hline ॥T10 & $\begin{array}{l}\text { My co-worker will appreciate my support and } \\
\text { help. }\end{array}$ & 0.867 & 5.8 \\
\hline
\end{tabular}




\section{(Appendix A (continuation)) \\ SCALE ITEMS}

\begin{tabular}{|c|c|c|c|}
\hline LV | Item & Item & $\begin{array}{l}\text { Standardized } \\
\text { factor loading }\end{array}$ & $\begin{array}{c}\text { Mean } \\
\text { (scale from } \\
1 \text { to } 7 \text { ) }\end{array}$ \\
\hline \multicolumn{4}{|l|}{ PC_pci } \\
\hline $\mathrm{PCl}$ & I consider myself a creative person. & 0.719 & 5.6 \\
\hline $\mathrm{PCl}$ & My creativity is important for who I am. & 0.825 & 5.6 \\
\hline PCI7 & Being a creative person is important to me & 0.788 & 6.0 \\
\hline $\mathrm{PCl} 10$ & Creativity is an important part of me. & 0.800 & 5.6 \\
\hline $\mathrm{PCl} 11$ & $\begin{array}{l}\text { Ingenuity is a characteristic which is important } \\
\text { to me. }\end{array}$ & 0.723 & 5.3 \\
\hline \multicolumn{4}{|l|}{ PC_aec } \\
\hline AEC3 & $\begin{array}{l}\text { I know I can efficiently solve even complicated } \\
\text { problems }\end{array}$ & 0.664 & 5.5 \\
\hline AEC4 & I trust my creative abilities. & 0.830 & 6.0 \\
\hline AEC5 & $\begin{array}{l}\text { Compared to my friends, I am distinguished by } \\
\text { my imagination and ingenuity. }\end{array}$ & 0.604 & 4.9 \\
\hline AEC6 & $\begin{array}{l}\text { Many times I have proved that I can cope with } \\
\text { difficult situations. }\end{array}$ & 0.649 & 5.7 \\
\hline AEC8 & $\begin{array}{l}\text { I am sure I can deal with problems requiring } \\
\text { creative thinking. }\end{array}$ & 0.811 & 5.6 \\
\hline AEC9 & $\begin{array}{l}\text { I am good at proposing original solutions to } \\
\text { problems. }\end{array}$ & 0.714 & 5.2 \\
\hline \multicolumn{4}{|l|}{ ST_swSp } \\
\hline SWSP1 & I found a meaningful career. & 0.538 & 5.1 \\
\hline SWSP4 & $\begin{array}{l}\text { I understand how a work contributes to my } \\
\text { life's meaning. }\end{array}$ & 0.804 & 6.4 \\
\hline SWSP5 & $\begin{array}{l}\text { I have a good sense of what makes my job } \\
\text { meaningful. }\end{array}$ & 0.677 & 6.2 \\
\hline SWSP8 & $\begin{array}{l}\text { I have found a work that has a satisfying } \\
\text { purpose. }\end{array}$ & 0.696 & 5.8 \\
\hline
\end{tabular}




\section{(Appendix A (continuation)) \\ SCALE ITEMS}

\begin{tabular}{|c|c|c|c|}
\hline LV | Item & Item & $\begin{array}{l}\text { Standardized } \\
\text { factor loading }\end{array}$ & $\begin{array}{c}\text { Mean } \\
\text { (scale from } \\
1 \text { to } 7 \text { ) }\end{array}$ \\
\hline \multicolumn{4}{|l|}{ ST_swft } \\
\hline SWFT2 & $\begin{array}{l}\text { I view my work as contributing to my personal } \\
\text { growth. }\end{array}$ & 0.632 & 6.4 \\
\hline SWFT7 & My work helps me better understand myself. & 0.888 & 5.9 \\
\hline SWFT9 & $\begin{array}{l}\text { My work helps me make sense of the world } \\
\text { around me. }\end{array}$ & 0.803 & 5.8 \\
\hline \multicolumn{4}{|l|}{ ST_swmm } \\
\hline SWMM3 & My work really makes difference to the world. & 0.822 & 5.8 \\
\hline SWMM6 & $\begin{array}{l}\text { I know my work makes a positive difference in } \\
\text { the world. }\end{array}$ & 0.758 & 6.0 \\
\hline SWMM10 & The work I do serves a greater purpose. & 0.735 & 6.2 \\
\hline SWMM11 & $\begin{array}{l}\text { A future job means for me the opportunity to } \\
\text { build a more solidary and just society. }\end{array}$ & 0.718 & 6.2 \\
\hline SWMM12 & A future job means to me a way to help others. & 0.754 & 6.3 \\
\hline \multicolumn{4}{|l|}{ EMP_aeat } \\
\hline AEAT21 & $\begin{array}{l}\text { Adapt myself to the changes that may occur in } \\
\text { my job functions. }\end{array}$ & 0.818 & 5.9 \\
\hline AEAT23 & To fulfill all tasks that the position demands. & 0.773 & 6.4 \\
\hline AEAT24 & $\begin{array}{l}\text { Demonstrate commitment to fulfill } \\
\text { professional duties. }\end{array}$ & 0.782 & 6.5 \\
\hline AEAT25 & Demonstrate safety in work activities. & 0.726 & 6.4 \\
\hline AEAT27 & Adapt myself to the needs of the workplace. & 0.713 & 6.4 \\
\hline \multicolumn{4}{|l|}{ EMP_aere } \\
\hline AERE7 & $\begin{array}{l}\text { Continue to seek employment, even if you } \\
\text { have many negative responses. }\end{array}$ & 0.855 & 6.2 \\
\hline AERE9 & $\begin{array}{l}\text { After a refusal to work, you can deal with } \\
\text { frustration. }\end{array}$ & 0.755 & 5.4 \\
\hline
\end{tabular}




\section{(Appendix A (conclusion)) \\ SCALE ITEMS}

\begin{tabular}{|c|c|c|c|}
\hline LV | Item & Item & $\begin{array}{l}\text { Standardized } \\
\text { factor loading }\end{array}$ & $\begin{array}{c}\text { Mean } \\
\text { (scale from } \\
1 \text { to } 7 \text { ) }\end{array}$ \\
\hline AEREI3 & $\begin{array}{l}\text { Do not be discouraged by the difficulties } \\
\text { encountered in finding a job. }\end{array}$ & 0.869 & 6.0 \\
\hline AEREI4 & $\begin{array}{l}\text { After a denial of employment, do not let me } \\
\text { invade by negative thoughts. }\end{array}$ & 0.800 & 5.8 \\
\hline AERE16 & $\begin{array}{l}\text { Continue to think that I will find work after a } \\
\text { denial of employment. }\end{array}$ & 0.859 & 6.2 \\
\hline \multicolumn{4}{|l|}{ EMP_aepe } \\
\hline AEPEI & Respond to job postings. & 0.718 & 5.2 \\
\hline AEPE2 & Register with Employment Agencies. & 0.713 & 5.3 \\
\hline AEPE4 & Look for job opportunities on the Internet. & 0.736 & 4.8 \\
\hline AEPEG & $\begin{array}{l}\text { Register myself in recruitment and selection } \\
\text { agencies. }\end{array}$ & 0.714 & 5.2 \\
\hline AEPE8 & $\begin{array}{l}\text { Register with employment agencies on the } \\
\text { Internet. }\end{array}$ & 0.806 & 4.5 \\
\hline
\end{tabular}

Note: All factor loadings are significant $(p<0.001)$. These results are CFA with 10 first-order LVs (Table 2). One sample of the items was presented here given space, but the results of the 48 items are available with the first author.

Legend: IST = Social Importance at Work; IIT = Interpersonal Importance at Work; CP = Creative Personality; AEC = Creative Self-efficacy; SWSP = Positive Meaning of Work; SWFT = Meaning Making through Work; SWMM = Greater Good Motivations; AEAT = Self-efficacy in Adaption to Work; AERE = Self-efficacy in Emotional Regulation; AEPE = Self-efficacy in Job Search.

Source: Elaborated by the authors.

EDITORIAL BOARD

Editors-in-chief

Janette Brunstein

Silvio Popadiuk

Associated Editor

Pedro Bendassolli

Technical Support

Vitória Batista Santos Silva

\section{EDITORIAL PRODUCTION}

$\begin{array}{ll}\begin{array}{l}\text { Publishing Coordination } \\ \text { Irina Migliari }\end{array} & \begin{array}{l}\text { Layout Designer } \\ \text { Emap }\end{array} \\ \text { Copyeditor } & \text { Graphic Designer } \\ \text { Irina Migliari (English) } \\ \text { Carlos Villarruel (Portuguese) } \\ \text { Libro } \\ \text { Language Editor } \\ \text { Daniel de Almeida Leão (English) } \\ \text { Irina Migliari (Portuguese) }\end{array}$

